\title{
p-Type Polymers for Templated Crystallization of Perovskite Films and Interface Optimization for High Performance Solar Cells
}

\author{
Wei-Wei Zuo ${ }^{1}{ }^{\mathbb{D}}$, Weifei Fu ${ }^{2, *}$, Wan-Sheng Zong ${ }^{1}$, Shen-Gang $\mathrm{Xu}^{1}{ }^{1} *$, Ying-Liang Liu ${ }^{1}$ and Shao-Kui Cao ${ }^{1, *}$ \\ 1 Henan Key Laboratory of Advanced Nylon Materials and Application, School of Materials Science and \\ Engineering, Zhengzhou University, Zhengzhou 450001, China; weezuo@gmail.com (W.-W.Z.); \\ ip182@stud.uni-heidelberg.de (W.-S.Z.); liuylxn@zzu.edu.cn (Y.-L.L.) \\ 2 State Key Laboratory of Silicon Materials, Department of Polymer Science and Engineering, \\ Zhejiang University, Hangzhou 310027, China \\ * Correspondence: zjufwf@zju.edu.cn (W.F.); xusg@zzu.edu.cn (S.-G.X.); caoshaokui@zzu.edu.cn (S.-K.C.)
}

Citation: Zuo, W.-W.; Fu, W.; Zong, W.-S.; Xu, S.-G.; Liu, Y.-L.; Cao, S.-K. p-Type Polymers for Templated Crystallization of Perovskite Films and Interface Optimization for High Performance Solar Cells. Crystals 2021, 11, 654. https://doi.org/ $10.3390 /$ cryst 11060654

Academic Editor: Sergey V. Makarov

Received: 11 May 2021

Accepted: 7 June 2021

Published: 9 June 2021

Publisher's Note: MDPI stays neutral with regard to jurisdictional claims in published maps and institutional affiliations.

Copyright: (c) 2021 by the authors. Licensee MDPI, Basel, Switzerland. This article is an open access article distributed under the terms and conditions of the Creative Commons Attribution (CC BY) license (https:/ / creativecommons.org/licenses/by/ $4.0 /)$.

\begin{abstract}
The purity of the perovskite material is of paramount importance as it determines the optoelectronic properties and, hence, the device performance. However, the error during the experiment and incomplete crystallization is inevitable, leading to a low quality. Here, two p-type polymers were designed to template the crystallization of perovskite to obtain perovskite films with higher crystallinity and higher phase purity. The polymers at the perovskite/transport interface could also improve the charge transfer and, thus, the device performance. In this study, the highest efficiency device achieved an efficiency value of $\sim 19 \%$ with improved open-circuit voltage and fill factor.
\end{abstract}

Keywords: templated crystallization; interface; perovskite; solar cells

\section{Introduction}

Due to the solution-processability and high performance, perovskite solar cells (PSCs) are the "rising star" in the photovoltaics field. The power conversion efficiency (PCE) of PSCs has rapidly increased from $3.8 \%$ to $25.5 \%$ in less than 15 years [1,2]. Most state-of-theart PSCs are solution-based and low-temperature compatible $\left(<100{ }^{\circ} \mathrm{C}\right)$, promoting low-cost commercialization possibilities. In a solar cell, charge carrier generation, collection, and transport layers are stacked together. The transport layers and the interfaces significantly influence the carrier transport and collection, which are significant for performance. Defects, especially defects at the interface, are among the most critical factors for the stability of PSCs.

Additives, such as polymers and conjugated molecules, including fullerenes, are widely used in anti-solvent treatment, mainly for defect passivation, optimizing the nucleation and growth of the perovskite film, and a more desired interface between perovskite and the transporting layer [3]. For example, Grätzel et al. introduced poly(methyl methacrylate) (PMMA) as a template to control nucleation and crystal growth of perovskite to achieve high electronic quality films; thus, a certified PCE of $21.02 \%$ under the standard AM 1.5G reporting conditions was achieved [4]. p-type conjugated polymers, such as poly[(2,6-(4,8-bis(5-(2-ethylhexyl) thiophen-2-yl)-benzo[1,2-b:4,5- $\left.\mathrm{b}^{\prime}\right]$ dithiophene))-alt(5,5-(1', $3^{\prime}$-di-2-thienyl-5', $7^{\prime}$-bis(2-ethylhexyl) benzo[1 $\left.1^{\prime}, 2^{\prime}-\mathrm{c}: 4^{\prime}, 5^{\prime}-\mathrm{c}^{\prime}\right]$ dithiophene-4,8-dione) $]$ (PBDB-T) [5], poly(bithiophene imide) (PBTI) [6], and dithienobenzodithiophene-based $\pi$-conjugated polymer PDTBDT-FBT [7] were also introduced during the anti-solvent process, which could passivate the perovskites. These conjugated polymers could also help to realize ultrafast charge transfer at the interface due to the cascade energy level landscape. Furthermore, ionic migration at the interface of PSCs limits the efficiency of PSCs [8-11]. Ion migration, either to the perovskite/electron transport layer (ETL) or perovskite/hole 
transport (HTL) interfaces, may result in undesirable reactions between $\mathrm{I}^{-}$and the transport layers or metal electrode. Carrillo et al. found that a neutral spiro-OMeTAD ${ }^{-}$iodide complex will be formed by a chemical reaction between the oxidized spiro-OMeTAD ${ }^{+}$ and $\mathrm{I}^{-}$ions [12]. The conductivity of HTLs and the device performance will decrease by the irreversible chemical reactions at the perovskite/spiro-OMeTAD interface. The local contact potential distribution at the oxidized spiro-OMeTAD layer after light illumination will change because of the reaction [13]. Kim et al. found that the oxidized spiro-OMeTAD ${ }^{+}$ and $\mathrm{I}^{-}$ions could also be activated to react with a temperature of $>85^{\circ} \mathrm{C}$ [14]. The mobile $\mathrm{I}^{-}$ions could also react with metal electrodes, such as silver [15]. Kato et al. found that silver electrodes of $\mathrm{MAPbI}_{3}$ cells will turn yellow within days. They proposed that $\mathrm{Ag}$ will migrate across the spiro-OMeTAD layer through pinholes and react with MAI to form AgI [15].

Hence, in this work, p-type polymers, based on carbazole and triphenylamine, were designed to template crystallization of perovskite film, and isolate the ions from the spiroOMeTAD and electrode at the same time. Excess lead iodide decreases and the crystallinity increases, indicating higher film quality with less defects. The device efficiency improved with polymer-templated crystallization. The highest efficiency device shows an efficiency of $19.15 \%$ with PTPA-mCP templated crystallization from $17.79 \%$ for the control device.

\section{Experimental}

\subsection{Fabrication of Perouskite Solar Cells}

Au was ordered from LUOHONGKEJI (Shijiazhuang, Hebei, China). DMF and DMSO were purchased from Sigma-Aldrich (Beijing, China). Unless otherwise specified, other chemicals in this article were ordered from Xi'an Polymer Light Technology Corp. (Xi'an, Shaanxi, China), and no further purification was conducted before use. A device structure of $\mathrm{FTO} / \mathrm{SnO}_{\mathrm{x}} /$ triple-cation perovskite/spiro-OMeTAD/Au was used to fabricate solar cells. The substrates were washed by ultrasonication in deionized water, acetone, and isopropanol sequentially. UV-Ozone further treated the substrates for $15 \mathrm{~min}$, and the $\mathrm{SnO}_{\mathrm{x}}$ layer was deposited by chemical bath deposition (CBD) as ETL. In the chemical bath solution, tin chloride dihydrate $\left(\mathrm{SnCl}_{2} \cdot 2 \mathrm{H}_{2} \mathrm{O}\right)(0.02 \mathrm{~g})$, urea $(0.05 \mathrm{~g})$, mercaptoacetic acid $(1 \mu \mathrm{L})$, and hydrochloride acid $(\mathrm{HCl}$, aq $37 \%)(50 \mu \mathrm{L})$ were added into ultra-pure water $(80 \mathrm{~mL})$ in a bottle, and shook for $10 \mathrm{~min}$. The cleaned FTO substrates were immersed into the prepared solution and then transferred into the oven at $75^{\circ} \mathrm{C}$ for $4 \mathrm{~h}$. The samples were annealed at $180^{\circ} \mathrm{C}$ for one hour and treated by UV-Ozone for $15 \mathrm{~min}$. The perovskite precursor was prepared with a composition of $\mathrm{Cs}_{0.05}\left(\mathrm{FA}_{0.85} \mathrm{MA}_{0.15}\right)_{0.95} \mathrm{~Pb}\left(\mathrm{I}_{0.85} \mathrm{Br}_{0.15}\right)_{3}$. Firstly, CsI was dissolved in DMSO (1.5 M), $\mathrm{PbI}_{2}$ and $\mathrm{PbBr}_{2}$ solutions $(1.5 \mathrm{M})$ were prepared independently in a mixture of DMF/DMSO $(v / v=4: 1)$. $\mathrm{FAPbI}_{3}$ and $\mathrm{MAPbBr}_{3}$ precursors $(1.24 \mathrm{M})$ were prepared by adding an appropriate volume of $\mathrm{PbI}_{2}$ and $\mathrm{PbBr}_{2}$ and an appropriate volume of DMF:DMSO into FAI and MABr. The MABr:PbBr 2 and FAI:PbI ratio was 1:1.09. $\mathrm{FAPbI}_{3}$ and $\mathrm{MAPbBr}_{3}$ perovskite solutions were mixed at 85:15 $(v / v)$, and $5 \%$ CsI solution was further added into the solution to get the desired triple cation perovskite precursor. The PCz-mCP and PTPA-mCP solutions were prepared in toluene with a concentration of $0.1 \mathrm{mM}$, which were used as anti-solvent $(60 \mu \mathrm{L})$ for perovskite film deposition. The perovskite films were annealed on a hot plate at $100{ }^{\circ} \mathrm{C}$ for $40 \mathrm{~min}$. SpiroOMeTAD solution in chlorobenzene was prepared with a concentration of $28.4 \mathrm{mM}$. LiTFSI (lithium bis(trifluoromethanesulfonyl)imide) and FK209 Co(III)TFSI (tris(2-(1H-pyrazol-1yl)-4-tertbutylpyridine)cobalt(III) tri[bis(trifluoromethane)sulfonimide]) were prepared in acetonitrile with the concentration of 0.2 and $1.8 \mathrm{M}$, respectively. LiTFSI ( $8.8 \mathrm{~mL})$, FK209 $(14.5 \mathrm{~mL})$, and tBP (4-tert-Butypyridine) $(14.4 \mathrm{~mL})$ were added into spiro-OMeTAD solution $(1 \mathrm{~mL})$. Then, the solution was deposited on the top of perovskite to form the hole transport layer by spin-coating at $1800 \mathrm{rpm}$ for $30 \mathrm{~s}$. The samples were transferred into a dry air box for $24 \mathrm{~h}$ before the deposition of $80 \mathrm{~nm} \mathrm{Au}$. 


\subsection{Characterization}

The $J-V$ curves of solar cells were measured with a Wavelabs Sinus-70 LED class AAA solar simulator (Suzhou, Jiangsu, China) and the measurement was conducted in air with a Keithley 2400 SMU (Beijing, China). The light intensity was calibrated with a Fraunhofer ISE Silicon reference cell (Freiburg, Germany). The active device area was $0.144 \mathrm{~cm}^{2}$. XPS measurements were conducted by a Kratos AXIS Untraded ultrahigh vacuum (UHV) surface analysis system (Santa Clara, CA, USA), and the binding energy of $\mathrm{C} 1 \mathrm{~s}(285.00 \mathrm{eV})$ was used as the reference. The absorbance spectra were measured with a UV-vis spectrophotometer (PerkinElmer Lambda 750) (Santa Clara, CA, USA). Scanning electron microscope (SEM) images were collected through a field emission SEM (Quanta 200 FEG, FEI Co.) (Hillsboro, OR, USA). X-ray diffraction (XRD) patterns were performed by a PANalytical 80 equipment (Empyrean, $\mathrm{Cu}$ Ka radiation) (Shanghai, China). The steadystate photoluminescence (PL) spectra were acquired using Horiba Jobin-Yvon LabRAM HR800 (Beijing, China) and excited at $480 \mathrm{~nm}$. Fourier Transform Infrared (FTIR) spectra were conducted on a BRUCK Tensor II FTIR spectrometer.

\section{Results and Discussion}

In this study, two polymers named PCz-mCP and PTPA-mCP were designed (Figure 1). Carbazole $(\mathrm{Cz})$ and triphenylamine (TPA)-based molecules were considered because $\mathrm{Cz}$ derivatives, such as 2PACz [16] and poly-N-vinylcarbazole (PVK) [17], and TPA derivatives, such as poly[bis(4-phenyl)(2,5,6-trimethylphenyl)amine (PTAA) [18] and spiro-OMeTAD [19], are the most widely used HTMs in PSCs. Moreover, an electron transport functional group, triazole, was added in the branch, and the unit 1,3-bis $(9 \mathrm{H}-$ carbazol9-yl)benzene ( $\mathrm{mCP}$ ) onto the pre-obtained triphenylamine-carbazole alternating copolymers [20]. As the buffer layer at the interface, the p-type polymers include an electron transport group, and could avoid molecular polarization during device-working, which would help the device keep stable for a long time [21]. The triple-cation perovskite $\left(\mathrm{Cs}_{0.05}\left(\mathrm{MA}_{0.15} \mathrm{FA}_{0.85}\right)_{0.95} \mathrm{~Pb}\left(\mathrm{I}_{0.85} \mathrm{Br}_{0.15}\right)_{3}\right)$ was used as the absorber.
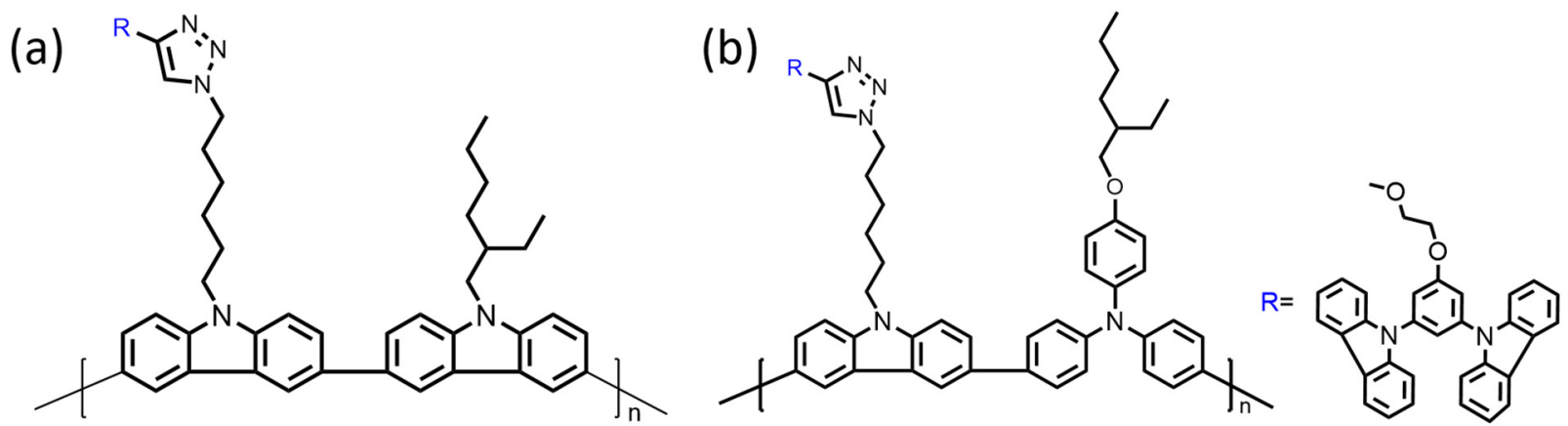

Figure 1. Molecular structures of (a) PCz-mCP and (b) PTPA-mCP.

In Figure 2a, we find that the peak at $\sim 14.4^{\circ}$ is significantly higher for the polymertemplated crystallized films. The peaks at $11.6^{\circ}$ and $12.7^{\circ}$, which correspond to the $\delta$-phase of $\mathrm{FAPbI}_{3}$ and $\mathrm{PbI}_{2}$, disappeared with polymer-templated crystallization, indicating a superior phase purity with PCz-mCP and PTPA-mCP templated crystallization. This may be attributed to the lower free energy barrier of nucleation with polymers in the antisolvent, which facilitates the heterogeneous nucleation. FA-based perovskites could not completely convert into the photoactive $\alpha$-phase [22]. Moreover, the absorption spectra in Figure $2 \mathrm{~b}$ shows that the absorb intensity slightly changed from control to PCz-mCP and PTPA-mCP templated crystallization, without changing the maximum absorbance edge. This suggests a slightly light absorbance change, but has no influence on the bandgap. FTIR spectra were performed to investigate the interaction between interface polymers and the perovskite by analyzing vibrational modes. According to Tobias Glaser et al. [23], the 
peaks showed no difference (see Figure 2c) when the perovskite film underwent templated crystallization with polymers, which means that the polymers did not affect the ionic motion (such as methylammonium vibrations). From the top view SEM images, we can see that the perovskite films with polymer-templated crystallization are smoother than the control film, due to the higher purity (Figure $2 \mathrm{~d}-\mathrm{f}$ ).
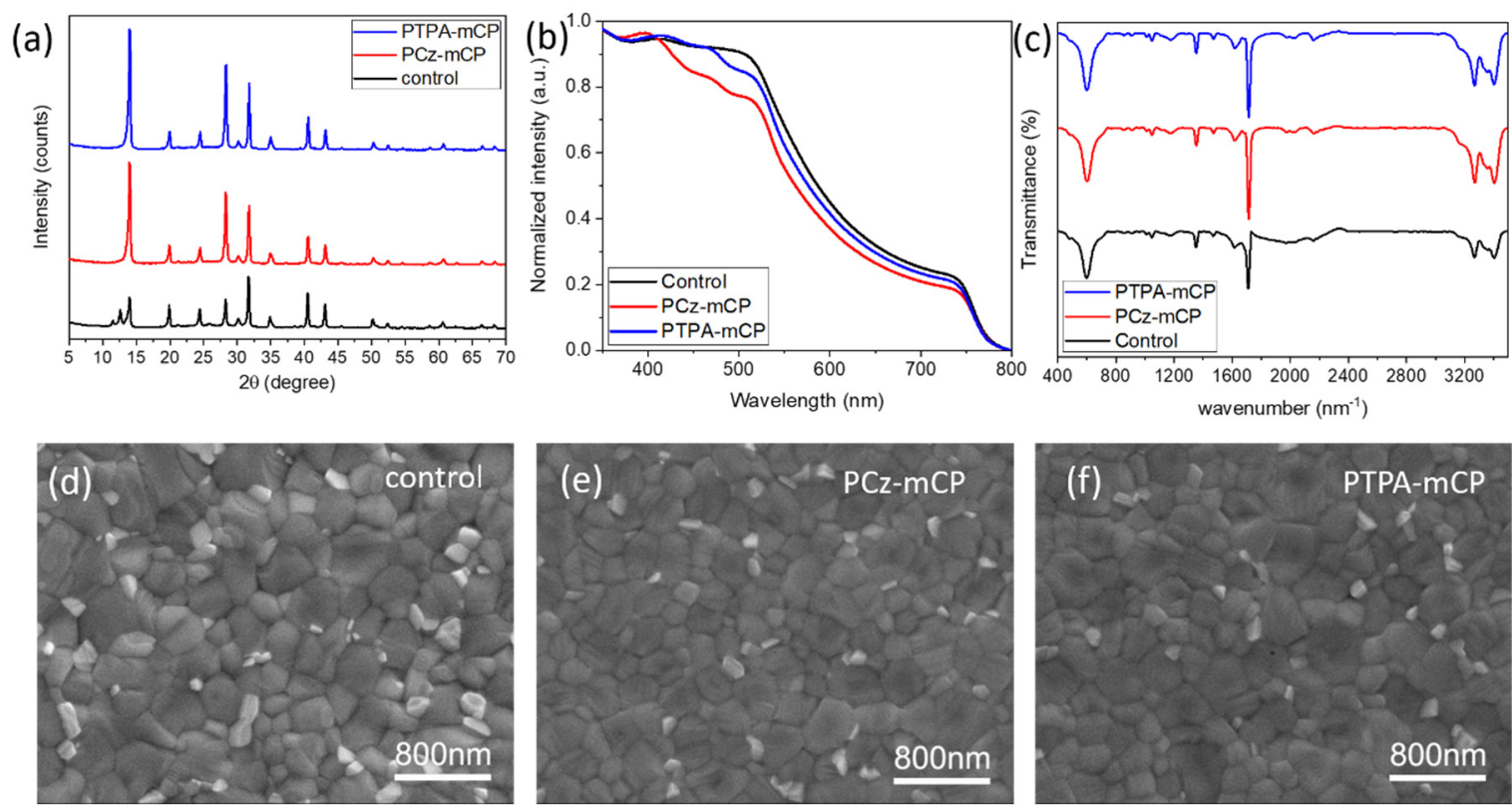

Figure 2. (a) XRD pattern of PCz-mCP and PTPA-mCP modified perovskite films; (b) normalized UV-vis curve and (c) FTIR spectra of control and modified perovskite film with PCz-mCP and PTPA-mCP; top-view SEM images of perovskite films: (d) control, (e) PCz-mCP, and (f) PTPA-mCP modified films.

Figure 3a shows the photoluminescence (PL) spectra of the perovskite films with or without polymer-templated crystallization. We can see that the PL intensity decreases with polymer-templated crystallization, which may be attributed to a more efficient charge transfer between perovskite and transport layers. Time-resolved photoluminescence spectroscopy (TRPL) shown in Figure 3b also indicates the more efficient charge transfer between perovskite films and transport layers with polymer-templated crystallization. PTPA-mCP modified perovskite film shows the shortest PL lifetime, which means the fastest charge transfer between perovskite and spio-oMETAD. These results indicate an improved interface at the perovskite and HTL.
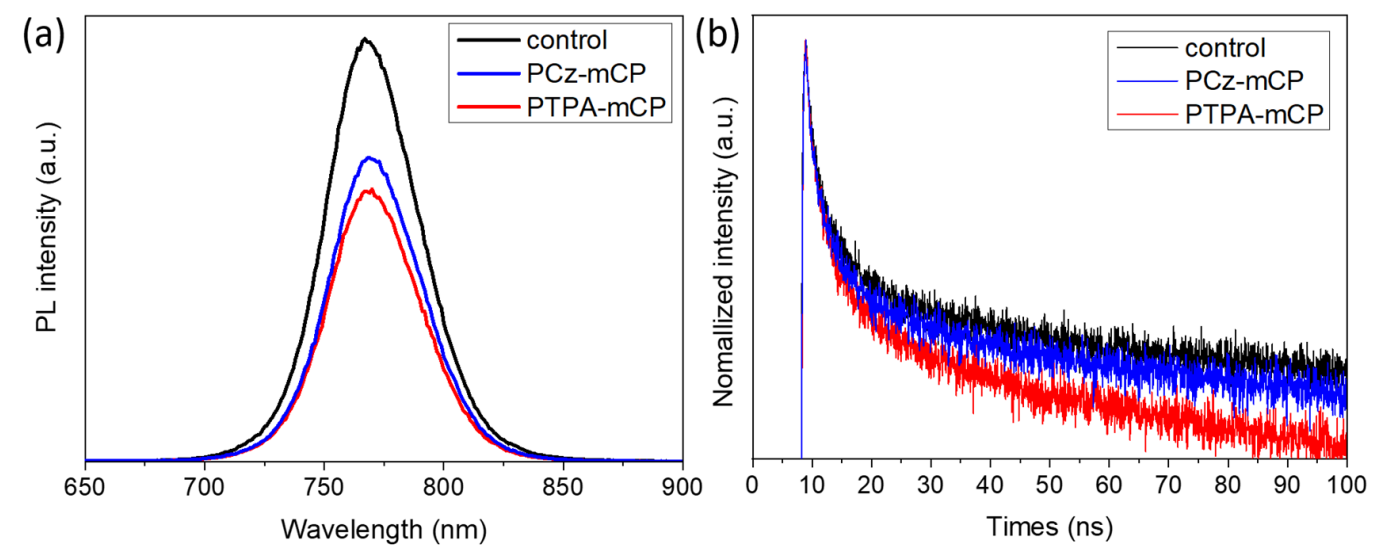

Figure 3. (a) PL spectrum of the control film, PCz-mCP, and PTPA-mCP modified perovskite films; (b) TRPL spectrum of the control and modified film measured by the structure of $\mathrm{FTO} / \mathrm{SnO}_{2} /$ perovskite. 
In order to investigate the chemical state of the elements in both the control film and the PCz-mCP, and the PTPA-mCP modified perovskite films, high-resolution XPS was conducted (Figure 4a). The observed XPS peaks are similar to that in the literature [24-26]. The peaks of $\mathrm{Pb}$ and I did not change, with or without polymer-templated crystallization, implying an unchanged chemical environment of these two elements.
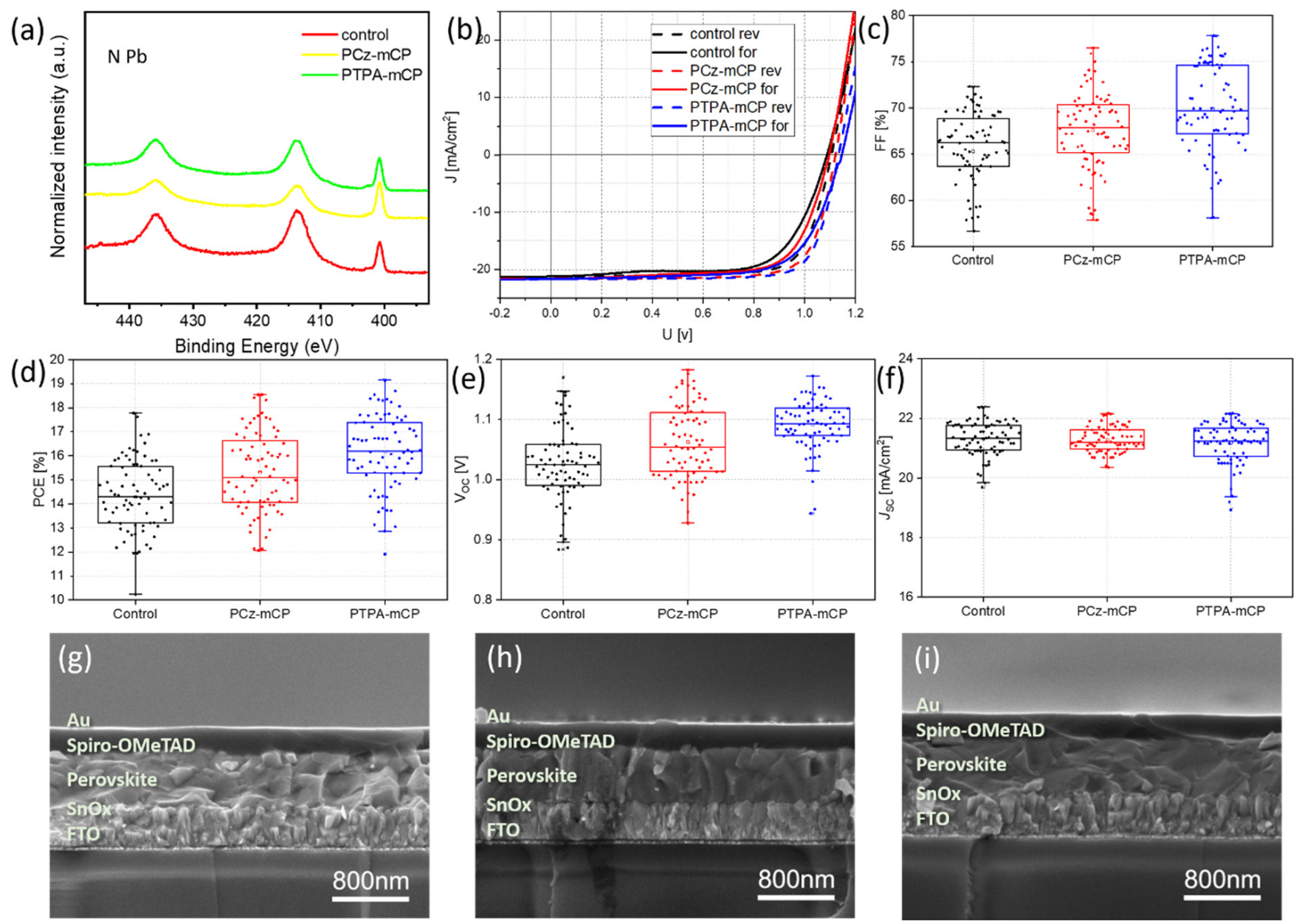

Figure 4. (a) XPS spectra of $\mathrm{Pb} 4 \mathrm{~d}$ and $\mathrm{N}$ 1s and (b) $J-V$ curves of the comparison between the control film and PCz-mCP and PTPA-mCP modified perovskite films. Box chart of the (c) FF, (d) PCE, (e) $V_{\mathrm{OC}}$, and (f) $J_{\mathrm{SC}}$ of different devices. Cross-sectional SEM images of (g) control, (h) PCz-mCP, and (i) PTPA-mCP modified devices.

PSCs were fabricated to investigate the effect of polymer-templated crystallization and interface optimization on device performances. The perovskite layer was deposited on glass/FTO/SnOx substrates. The compact $\mathrm{SnO}_{\mathrm{x}}$ layer was deposited by the CBD method and works as the electron transport layer. The cross-sectional SEM images shown in Figure $4 \mathrm{~g}-\mathrm{i}$ show that the thickness of the perovskite layer in the control device and the modified device is about $620 \mathrm{~nm}$.

The $J-V$ curves were measured under simulated AM 1.5G sunlight conditions in both forward and reverse scan directions. When employing PTPA-mCP in the antisolvent, a PCE of $19.15 \%$ was achieved with excellent reproducibility. The $J-V$ curves of the best cells with or without polymer-templated crystallization are shown in Figure $4 \mathrm{~b}$, and detailed data are shown in Table 1. The hysteresis index (HI) was calculated by Equation (1).

$$
\mathrm{HI}=\frac{\mathrm{PCE}(\text { Reverse })-\mathrm{PCE}(\text { Forward })}{\mathrm{PCE}(\text { Reverse })}
$$


p-type polymer addition in antisolvent could reduce $\mathrm{HI}$, increase the $V_{\mathrm{OC}}$, and fill factor (FF) (see Figure $4 \mathrm{c}-\mathrm{f}$ ), which is consistent with the reduced defectivity of the perovskite interface. The higher FF could be attributed to the reduced series resistance $\left(R_{s}\right)$ and increased shunt resistance $\left(R_{s h}\right)$ [27]. According to the results of XRD, SEM, PL, TRRPL, the improvement of device performance was attributed to the better film quality with less defects (bulk) and better charge transfer between perovskite and the spiro-OMeTAD (interface).

Table 1. Comparison of photovoltaic parameters of the highest efficiency devices based on perovskite films with or without polymertemplated crystallization.

\begin{tabular}{|c|c|c|c|c|c|c|c|}
\hline $\begin{array}{l}\text { Perovskite (Scan } \\
\text { Direction) }\end{array}$ & $\begin{array}{c}J_{\mathrm{SC}} \\
\left(\mathrm{mA} / \mathrm{cm}^{2}\right)\end{array}$ & $V_{\text {OC }}(\mathrm{mV})$ & FF (\%) & PCE (\%) & $\begin{array}{c}R_{S} \\
\left(\Omega \mathrm{cm}^{2}\right)\end{array}$ & $\underset{\left(\Omega \mathrm{cm}^{2}\right)}{R_{S h}}$ & HI \\
\hline $\begin{array}{c}\text { PTPA-mCP } \\
\text { (Reverse) }\end{array}$ & 21.70 & 1134 & 78 & 19.15 & 4.4 & 5953.8 & \multirow{2}{*}{0.11} \\
\hline $\begin{array}{l}\text { PTPA-mCP } \\
\text { (Forward) }\end{array}$ & 21.66 & 1146 & 69 & 17.12 & 5.3 & 1903.0 & \\
\hline $\begin{array}{l}\text { PCz-mCP } \\
\text { (Reverse) }\end{array}$ & 21.61 & 1122 & 77 & 18.54 & 4.0 & 3591.0 & \multirow{2}{*}{0.10} \\
\hline $\begin{array}{l}\text { PCz-mCP } \\
\text { (Forward) }\end{array}$ & 21.62 & 1096 & 71 & 16.76 & 4.7 & 2327.2 & \\
\hline $\begin{array}{c}\text { control } \\
\text { (Reverse) }\end{array}$ & 21.81 & 1169 & 69 & 17.62 & 6.1 & 3079.0 & \multirow{2}{*}{0.2} \\
\hline $\begin{array}{c}\text { control } \\
\text { (Forward) }\end{array}$ & 21.74 & 1030 & 63 & 14.15 & 6.2 & 1315.1 & \\
\hline
\end{tabular}

$V_{\mathrm{OC}}$, open-circuit voltage; $J_{\mathrm{SC}}$, short-circuit current density; FF, fill factor; PCE, power conversion efficiency; $\mathrm{R}_{\mathrm{S}}$ : series resistance, $\mathrm{R}_{\mathrm{Sh}}$ : shunt resistance.

\section{Conclusions}

The reaction between spiro-OMeTAD and iodine will influence solar cell efficiency; thus, in this work, two polymers were synthesized as the buffer layer between perovskite film and spiro-OMeTAD. Furthermore, the perovskite films with polymer-templated crystallization show higher crystallinity and higher phase purity. Finally, a highest PCE of $19.15 \%$ was achieved with improved $V_{\mathrm{OC}}$ and FF compared with the control device.

Author Contributions: Conceptualization, W.-W.Z. and W.F.; methodology, W.-S.Z.; writing—original draft preparation, W.-W.Z.; writing-review and editing, W.F. and Y.-L.L.; supervision, S.-G.X. and S.-K.C.; project administration, S.-K.C.; funding acquisition, S.-K.C. All authors have read and agreed to the published version of the manuscript.

Funding: This research was funded by [the National Natural Science Foundation of China] grant number [U2004173, 21274133] and [the Open Fund of the State Key Laboratory of Luminescent Materials and Devices (South China University of Technology)] grant number [No. 2020-skllmd-08].

Institutional Review Board Statement: Not applicable.

Informed Consent Statement: Not applicable.

Data Availability Statement: The data presented in this study are openly available in [repository name e.g., FigShare] at [https://www.doi.org/], reference number [reference number].

Conflicts of Interest: The authors declare no conflict of interest.

\section{References}

1. Best Research-Cell Efficiency Chart. Available online: https:/ / www.nrel.gov / pv/ cell-efficiency.html (accessed on 8 June 2021).

2. Green, M.A.; Ho-Baillie, A.; Snaith, H.J. The emergence of perovskite solar cells. Nat. Photonics 2014, 8, 506-514. [CrossRef]

3. Sun, J.; Li, F.; Yuan, J.; Ma, W. Advances in Metal Halide Perovskite Film Preparation: The Role of Anti-Solvent Treatment. Small Methods 2021, 5, 7ff6. [CrossRef] 
4. Bi, D.; Yi, C.; Luo, J.; Décoppet, J.-D.; Zhang, F.; Zakeeruddin, S.M.; Li, X.; Hagfeldt, A.; Grätzel, M. Polymer-templated nucleation and crystal growth of perovskite films for solar cells with efficiency greater than 21\%. Nat. Energy 2016, 1, 16142. [CrossRef]

5. Qin, P.-L.; Yang, G.; Ren, Z.-w.; Cheung, S.H.; So, S.K.; Chen, L.; Hao, J.; Hou, J.; Li, G. Stable and Efficient Organo-Metal Halide Hybrid Perovskite Solar Cells via $\pi$-Conjugated Lewis Base Polymer Induced Trap Passivation and Charge Extraction. Adv. Mater. 2018, 30, 1706126. [CrossRef] [PubMed]

6. Chen, W.; Wang, Y.; Pang, G.; Koh, C.W.; Djurišić, A.B.; Wu, Y.; Tu, B.; Liu, F.-z.; Chen, R.; Woo, H.Y.; et al. Conjugated Polymer-Assisted Grain Boundary Passivation for Efficient Inverted Planar Perovskite Solar Cells. Adv. Funct. Mater. 2019, 29, 1808855. [CrossRef]

7. Li, X.; Li, W.; Yang, Y.; Lai, X.; Su, Q.; Wu, D.; Li, G.; Wang, K.; Chen, S.; Sun, X.W.; et al. Defects Passivation With Dithienobenzodithiophene-based $\pi$-conjugated Polymer for Enhanced Performance of Perovskite Solar Cells. Sol. RRL 2019, 3, 1900029. [CrossRef]

8. Islam, M.S. Ionic transport in $\mathrm{ABO}_{3}$ perovskite oxides: A computer modelling tour. J. Mater. Chem. 2000, 10, 1027-1038. [CrossRef]

9. Xing, J.; Wang, Q.; Dong, Q.; Yuan, Y.; Fang, Y.; Huang, J. Ultrafast ion migration in hybrid perovskite polycrystalline thin films under light and suppression in single crystals. Phys. Chem. Chem. Phys. 2016, 18, 30484-30490. [CrossRef]

10. Richardson, G.; O'Kane, S.E.; Niemann, R.G.; Peltola, T.A.; Foster, J.M.; Cameron, P.J.; Walker, A.B. Can slow-moving ions explain hysteresis in the current-voltage curves of perovskite solar cells? Energy Environ. Sci. 2016, 9, 1476-1485. [CrossRef]

11. Zuo, W.-W.; Li, M.; Zong, W.-S.; Xu, S.-G.; Liu, Y.-L.; Su, Z.-H.; Gao, X.-Y.; Cao, S.-K.; Wang, Z.-K. Stabilization of Intrinsic Ions in Perovskite Solar Cells by Employment of a Bipolar Star-Shaped Organic Molecule as a Charge Transport Buffer. ACS Appl. Energy Mater. 2020, 3, 10632-10641. [CrossRef]

12. Carrillo, J.; Guerrero, A.; Rahimnejad, S.; Almora, O.; Zarazua, I.; Mas-Marza, E.; Bisquert, J.; Garcia-Belmonte, G. Ionic reactivity at contacts and aging of methylammonium lead triiodide perovskite solar cells. Adv. Energy Mater. 2016, 6, 1502246. [CrossRef]

13. Hermes, I.M.; Hou, Y.; Bergmann, V.W.; Brabec, C.J.; Weber, S.A. The interplay of contact layers: How the electron transport layer influences interfacial recombination and hole extraction in perovskite solar cells. J. Phys. Chem. Lett. 2018, 9, 6249-6256. [CrossRef]

14. Kim, S.; Bae, S.; Lee, S.-W.; Cho, K.; Lee, K.D.; Kim, H.; Park, S.; Kwon, G.; Ahn, S.-W.; Lee, H.-M. Relationship between ion migration and interfacial degradation of $\mathrm{CH}_{3} \mathrm{NH}_{3} \mathrm{PbI}_{3}$ perovskite solar cells under thermal conditions. Sci. Rep. 2017, 7, 1-9. [CrossRef]

15. Kato, Y.; Ono, L.K.; Lee, M.V.; Wang, S.; Raga, S.R.; Qi, Y. Silver iodide formation in methyl ammonium lead iodide perovskite solar cells with silver top electrodes. Adv. Mater. Interfaces 2015, 2, 1500195. [CrossRef]

16. Lin, Y.; Firdaus, Y.; Isikgor, F.H.; Nugraha, M.I.; Yengel, E.; Harrison, G.T.; Hallani, R.; El-Labban, A.; Faber, H.; Ma, C. Selfassembled monolayer enables hole transport layer-free organic solar cells with $18 \%$ efficiency and improved operational stability. ACS Energy Lett. 2020, 5, 2935-2944. [CrossRef]

17. Wu, W.; Zhang, S.; Li, Y.; Li, J.; Liu, L.; Qin, Y.; Guo, Z.-X.; Dai, L.; Ye, C.; Zhu, D. PVK-modified single-walled carbon nanotubes with effective photoinduced electron transfer. Macromolecules 2003, 36, 6286-6288. [CrossRef]

18. Wang, M.; Wang, H.; Li, W.; Hu, X.; Sun, K.; Zang, Z. Defect passivation using ultrathin PTAA layers for efficient and stable perovskite solar cells with a high fill factor and eliminated hysteresis. J. Mater. Chem. A 2019, 7, 26421-26428. [CrossRef]

19. Nguyen, W.H.; Bailie, C.D.; Unger, E.L.; McGehee, M.D. Enhancing the hole-conductivity of spiro-OMeTAD without oxygen or lithium salts by using spiro (TFSI) $)_{2}$ in perovskite and dye-sensitized solar cells. J. Am. Chem. Soc. 2014, 136, 10996-11001. [CrossRef]

20. O'Brien, D.F.; Burrows, P.E.; Forrest, S.R.; Koene, B.E.; Loy, D.E.; Thompson, M.E. Hole Transporting Materials with High Glass Transition Temperatures for Use in Organic Light-Emitting Devices. Adv. Mater. 1998, 10, 1108-1112. [CrossRef]

21. Cooper, T.G.; Hejczyk, K.E.; Jones, W.; Day, G.M. Molecular polarization effects on the relative energies of the real and putative crystal structures of valine. J. Chem. Theory Comput. 2008, 4, 1795-1805. [CrossRef] [PubMed]

22. Saliba, M.; Matsui, T.; Seo, J.Y.; Domanski, K.; Correa-Baena, J.P.; Nazeeruddin, M.K.; Zakeeruddin, S.M.; Tress, W.; Abate, A.; Hagfeldt, A.; et al. Cesium-containing triple cation perovskite solar cells: Improved stability, reproducibility and high efficiency. Energy Env. Sci. 2016, 9, 1989-1997. [CrossRef]

23. Glaser, T.; Müller, C.; Sendner, M.; Krekeler, C.; Semonin, O.E.; Hull, T.D.; Yaffe, O.; Owen, J.S.; Kowalsky, W.; Pucci, A. Infrared spectroscopic study of vibrational modes in methylammonium lead halide perovskites. J. Phys. Chem. Lett. 2015, 6, $2913-2918$. [CrossRef] [PubMed]

24. Xie, H.; Liu, X.; Lyu, L.; Niu, D.; Wang, Q.; Huang, J.; Gao, Y. Effects of precursor ratios and annealing on electronic structure and surface composition of $\mathrm{CH}_{3} \mathrm{NH}_{3} \mathrm{PbI}_{3}$ perovskite films. J. Phys. Chem. C 2015, 120, 215-220. [CrossRef]

25. Philippe, B.; Park, B.-W.; Lindblad, R.; Oscarsson, J.; Ahmadi, S.; Johansson, E.M.; Rensmo, H.k. Chemical and Electronic Structure Characterization of Lead Halide Perovskites and Stability Behavior under Different Exposures A Photoelectron Spectroscopy Investigation. Chem. Mater. 2015, 27, 1720-1731. [CrossRef]

26. Grasso, V.; Silipigni, L. X-ray photoemission spectra and x-ray excited Auger spectrum investigation of the electronic structure of $\mathrm{Pd}_{3}\left(\mathrm{PS}_{4}\right)_{2}$. J. Vac. Sci. Technol. A Vac. Surf. Film. 2003, 21, 860-865. [CrossRef]

27. Khadka, D.B.; Shirai, Y.; Yanagida, M.; Masuda, T.; Miyano, K. Enhancement in efficiency and optoelectronic quality of perovskite thin films annealed in MACl vapor. Sustain. Energy Fuels 2017, 1, 755-766. [CrossRef] 